\title{
Employee Commitment to Improving Work Performance with Remuneration as a Mediator
}

\author{
Sry Rosita, Dian Mala Fithriani, and Fitri Widiastuti \\ Fakultas Ekonomi dan Bisnis. Universitas Jambi, Jambi \\ Email: sry_rosita@unja.ac.id
}

\begin{abstract}
This study aims to examine employee commitment to improving work performance with remuneration as a mediator variable. The research objects discussed are; 1) Employee commitment, 2) Work performance and 3) Remuneration. The target of the study was 164 Civil Servants at the University of Jambi. The results showed that employee commitment has a greater influence on work performance if mediated by remuneration rather than the direct influence of employee commitment on work performance. This can be interpreted that remuneration which is a performance allowance to employees has a large role as a mediator on employee commitment which shows employee involvement to reach the goal so that it can improve work output which is the achievement of work performance.
\end{abstract}

Keywords: Employee Commitment, Remuneration, Work Performance.

\section{INTRODUCTION}

Employee commitment is an attitude to remain in the organization and can be involved in achieving the vision, mission, goals, and objectives of the organization so that it is a concrete form of loyalty that can be interpreted to the extent that employees devote their attention, ideas and responsibilities to the organization. The commitment of employees in carrying out their duties in carrying out work is necessary, but in growing the commitment of each employee to the organization cannot arise by itself, as a reason for the attitude of an employee to remain in the organization and involved in efforts to achieve the mission, values and goals The organization must be built from the beginning of the existence of employees in the organization.

The result of several studies revealed that employees who have a high commitment to working will produce optimal performance while employees who have low commitment will produce poor performance. The employees' commitments (Robbins and Judge, 2017) showed that an employee is in favor of an organization and its goals and desires to maintain membership in the organization. The measurement of employee commitment is characterized by three interrelated dimensions namely: Acceptance of organizational values, willingness to use business on behalf of the organization, and desire to stay with employees in one organization.

Research by (Lee and Chen, 2013) showed that employee commitment as one of the most important elements related to work performance. Some employees who are described as not committed at all to work, lazy, unprofessional, can be shown as people who work only to receive their salaries at the end of the month, and according to (Lee and Chen, 
2013), employee commitment is the basis for providing services that are quality. Another researcher by (Khan et all., 2010) investigated the impact of employee commitment on employee performance and the result revealed a positive relationship between employee commitment and employee performance, as well as research conducted by (Irefin and Mechanic, 2014) showed the result that employee commitment can improve work performance.

Performance appraisal is a formal process for reviewing and evaluating one's work performance periodically (Siagian, 2013). The work performance appraisal process is intended to understand a person's work performance with interrelated processes consisting of identification, observation, measurement, and development of employee work results in an organization, at the same time, employees need feedback on their work as a guide for behavior in the future. Performance appraisal procedure by (Handoko, 2012) stated that this can lead to an assessment of employee performance in the future and the future measurement is the most importantly related to various benchmarks, scales and assessment mechanisms that have been determined, evaluating employee performance determines the amount of bonuses, salary increases and speed of promotion, and employee remuneration.

Employee remuneration has the meaning as payment for work that has been done by an employee or as compensation for the performance of one's duties. Remuneration is a policy undertaken to reorganize the payroll system of Civil Servants in Indonesia so that Civil Servants can have better performance. The basic principle of remuneration is an award given to employees in the form of performance benefits based on rank and rank structure as well as civil servant remuneration mechanism guided by a merit system which is a determination of the number of benefits based on performance achievements, workloads, and grade at each rank.

Research by (Urbancová and Šnýdrová, 2017) regarding remuneration and benefits plays an important role in attracting and retaining employees in organizations. The remuneration given to each employee is different in its category. According to Urbancová and Šnýdrová, there are six benefits of remuneration, namely tangible benefits, social development, self-realization, social activities, personnel development, and other standard benefits. Research conducted by (Yuliani, 2015) showed that the remuneration system has a relationship with employee performance, the remuneration paid increases employee performance. Research conducted by (Wilfred, 2014) stated that poor work performance is caused by poor remuneration, with a fixed salary scale for a long time can reduce employee morale, therefore organizations need to consider the remuneration system as a mechanism by which the organization can plan, attract, maintain, reward and motivate employees so that they can improve work performance.

Employee performance allowance within the Ministry of Research \& Technology and Higher Education stated that in increasing the performance of civil servants during the bureaucratic reform carried out by Ministry of Research \& Technology who has a rank in Ministry of Research \& Technology earning income by applicable regulations; it also receives monthly performance benefits. The performance allowances for civil servants within the Ministry of Research \& Technology and Higher Education can be seen in Table 1 below: 
Table 1. Employee Performance Benefits in the Ministry of Research \& Technology and Higher Education

\begin{tabular}{|c|c|c|}
\hline No & Class Position & $\begin{array}{c}\text { Performance allowance per } \\
\text { class position }\end{array}$ \\
\hline 1 & 2 & 3 \\
\hline 1 & 17 & Rp22,842,000.00 \\
\hline 2 & 16 & $\mathrm{Rp} 17,413,000.00$ \\
\hline 3 & 15 & Rp12,518,000.00 \\
\hline 4 & 14 & $\operatorname{Rp} 9,600.000 .00$ \\
\hline 5 & 13 & $\operatorname{Rp} 7,293,000.00$ \\
\hline 6 & 12 & $\operatorname{Rp} 6,045,000.00$ \\
\hline 7 & 11 & $\operatorname{Rp} 4,519,000.00$ \\
\hline 8 & 10 & $\operatorname{Rp} 3,952,000.00$ \\
\hline 9 & 9 & $\operatorname{Rp} 3,348,000.00$ \\
\hline 10 & 8 & $\operatorname{Rp} 2,927,000.00$ \\
\hline 11 & 7 & $\operatorname{Rp} 2,616,000.00$ \\
\hline 12 & 6 & $\operatorname{Rp} 2,399,000.00$ \\
\hline 13 & 5 & $\operatorname{Rp} 2,199,000.00$ \\
\hline 14 & 4 & Rp 2,082,000.00 \\
\hline 15 & 3 & $\operatorname{Rp} 1,972,000.00$ \\
\hline 16 & 2 & $\operatorname{Rp} 1,867,000.00$ \\
\hline 17 & 1 & $\operatorname{Rp} 1,766,000.00$ \\
\hline
\end{tabular}

Source: (Presidential Regulation No. 32 of 2016)

The amount of performance allowance for each civil servant is not always the same as the amount determined based on the order of the class position. Civil servant work performance is still based on output-oriented and not outcome-oriented. It is shown that civil servant work performance is based on the level of achievement of employee work goals and performance appraisal that has been done and agreed collectively between civil servants and group of grantors that are grouped into two parts; the employee performance goals and work behavior.

Implicitly, the variable of employee commitment, variable work performance and remuneration is appropriately interesting to be researched and studied further; therefore it can be shown that the purpose of this study is to determine employee commitment in improving employee performance with remuneration as a mediator variable?

\section{THEORETICAL REVIEW}

Employee Commitment. According to (Akintayo, 2012) employee commitment is defined that employees have special positions in the organization. (Zheng et all., 2010) describe employee commitment only as employee attitudes toward the organization. Employee commitment shows the employee's decision in choosing an organization, the goals, and objectives of the organization, as well as his hopes to remain a member of the organization concerned. According to (Colquitt et all., 2015), the type of organizational commitment consists of: (1) Normative Commitment. Employees must always be in the 
organization due to ethical and etiquette factors. Normative commitment is an employee's feelings about obligations (bonds) to survive in the organization. (2) Sustainable commitment. The form of economic calculations that can be enjoyed by employees which assumes that the employees remain in the organization compared to the employee must leave the organization. Sustainable commitment is a condition in which employees feel the need to stay, where they think that leaving the company will be very detrimental to themselves. (3) Affective commitment. Emotions are shown by employees for their organization and are convinced of the norms that apply in the organization. Affective commitment shows the emotional connection, recognition, and participation of employees in the organization. Employees have high confidence in accepting targets, norms in the organization, together with a great desire and willingness to spend all necessary efforts to benefit the organization and remain a member of the organization.

According to (Robbins and Judge, 2017), there are four dimensions used to measure affective commitment in the form of: (1) Loyalty. Indicates the level of loyalty and loyalty of employees to the organization where the employee works. This aspect can be demonstrated through the size of the ability of employees to continue trying to achieve the highest career in the organization. (2) Pride. Measuring the level of employee pride in the organization at work; this proud attitude can be shown by the employee through his intensity in telling the organization where he works to individuals outside the organization. (3) job involvement. Assessing the ability of employees to participate in developing the organization. This participation can be reflected through employee attitudes to unify organizational problems with the employee. (4) emotional attachment. Employee's emotional bounds whether the norms that apply in the organization in line with the norms that are believed by the employee. Emotional attachment can be reflected based on employees' views related to familiarity in an organization, showing how important the organization is to employees and showing that employees feel they own the organization.

Work performance. According to (Mangkunegara, 2012) revealed that work performance is the result of work in quantity and quality achieved by an employee in carrying out the duties following the responsibilities given to employees by the process of performance appraisal carried out by the company leaders systematically based on the work assigned to employees.

Employee work performance is the result of performance measurements made with an assessment. The government established a new policy in evaluating the performance of civil servants by stipulating (Government Regulation Number 46 of 2011) an evaluation of the achievements of civil servants' work. Evaluation of the achievements of civil servants' work is a structured measurement mechanism carried out by the scoring party on 2 aspects: (1) Employee's work goals and (2) Civil Servant work behavior. Work performance is a performance that has been obtained by civil servants in each organization based on aspects of employee work goals and aspects of work behavior.

According to (Flippo, 2012) dimensions of work performance can be measured through: (1) Quality of work, related to time, expertise or skills and individual characteristics in completing work. (2) Work quantity, related to the contribution of extra 
work given by the leadership to its employees. (3) Responsibility, related to the evaluation of performance that has been completed and the use of work facilities. (4) Cooperation, relating to the behavior or actions shown by each employee by conducting cooperation so that the work can be completed better. (5) The initiative, related to the extent to which employees think originally and based on their initiative to solve the problems encountered.

Employee Remuneration. Remuneration is related to the prosperity of employees in an organization, remuneration is an appreciation for the achievement of the work done by employees for the organization to achieve goals. Remuneration tends to be interpreted as an assessment in the form of money, remuneration is considered effective to improve performance, show the level of effectiveness and efficiency of employees themselves. Remuneration provided properly and accurately and on target will motivate employees to continue to develop the employee's potential and organization.

Researchers at (BOL et all., 2015) mentioned that a fair remuneration system has to do with a performance appraisal system. The remuneration system includes a financial component (wages or salaries) and a non-financial component (additional benefits). Remuneration is an award given to employees in the form of performance benefits based on rank and rank system as well as employee remuneration mechanism guided by the merit system, namely the determination of the number of benefits based on performance achievements, workloads, and ranking of each rank.

The remuneration policy is aimed at all civil servants in all government agencies in Indonesia. Remuneration procedure is one part of the success of bureaucratic reform that is caused by a shift in culture that will affect the work processes of every employee in each organization to do the core work, therefore shifts to this culture tend to be easier to do.

(Agrimahera, 2013) stated that the application of the current civil servant remuneration system refers to 5 principles: (1) Merit system, the determination of employee income based on performance that is evaluated and assessed by referring to performance evaluation parameters. (2) Fair, means the position and workload and obligations have the same value then the same will be paid. For tasks that require employees to have specific knowledge in the field, and to have higher skills and power, they will be paid more. (3) Feasible, that is, it can fulfill the necessities of life properly. (4) Competitive, in which the remuneration of civil servants is equivalent to that in the private sector and the competencies held and carried by employees in carrying out their work as required. (5) Transparent, meaning that there is openness in determining the remuneration to determine the conditions for the increase, each of which must be known and easily understood by employees.

Research Framework. Considering to the previous findings regarding employee commitment, work performance, and remuneration that are not yet conclusive and caused by the limitations of empirical research, this study estimates that employee commitment can improve work performance with remuneration as a mediator variable, pictographically the basic research framework for this study presented image as follow: 
Figure 1. Model research framework

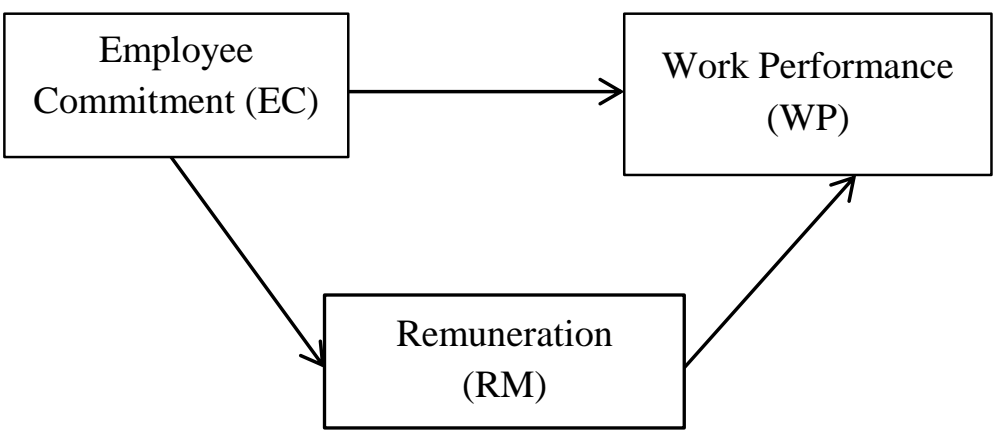

The employee commitment model for this research was formulated to consist of two: first the direct influence model, and second the mediated influence model. The direct influence model involved the construct of employee commitment and the consequences of it on work performance. The mediated influence model, remuneration, is a mediator in the relationship between employee commitment and work performance.

Hypothesis. From the formulation of the problem observed with the proposed theory so that the research conceptual model can be formulated the hypothesis, as follows: (1) Employee commitment influences improving work performance. (2) Employee commitment influences improving work performance with remuneration as a mediator variable.

\section{METHODOLOGY}

A descriptive type of research design is a quantitative approach. The target population is civil servants at the University of Jambi with a sample size of 164. The data needed to test the hypotheses submitted are entirely in the form of primary data obtained by distributing questionnaires to respondents. Data analysis tools used in this study are in the form of Partial Least Square (PLS), the software used is smart-PLS.

In detail about the operationalization of variables can be shown in table 2 below:

Table 2. Operational variables

\begin{tabular}{l|l|c|c}
\hline \multicolumn{1}{c|}{ Variables } & \multicolumn{1}{|c|}{ Dimension } & Scale & No Item \\
\hline $\begin{array}{l}\text { Employee Commitment } \\
\text { (EC) }\end{array}$ & $\begin{array}{l}\text { 1. Normative commitment } \\
\text { 2. Continuance commitment } \\
\text { 3. Affective commitment }\end{array}$ & Ordinal & $16-30$ \\
\hline Remuneration & $\begin{array}{l}\text { 1. Merit Systems } \\
\text { 2. Fair } \\
\text { 3. Feasible } \\
\text { 4. Competitive } \\
\text { 5. Transparent }\end{array}$ & Ordinal & $1-15$ \\
\hline
\end{tabular}




\begin{tabular}{l|l|c|c}
\hline Work Performance (WP) & $\begin{array}{l}\text { 1. Work Quality } \\
\text { 2. Work Quantity } \\
\text { 3. Responsibility } \\
\text { 4. Cooperation } \\
\text { 5. Initiative }\end{array}$ & & $40-42$ \\
& & & \\
\hline
\end{tabular}

Source: (developed for research submissions, 2018)

\section{THE RESULTS OF STATISTICAL TESTS}

Description of employee commitments. Descriptions of employee commitments have been implemented as shown in the following Table 3:

Table 3. Description of Employee Commitments

\begin{tabular}{|c|c|c|c|c|c|c|}
\hline Variables & Sub-Variables & No Item & $\begin{array}{c}\text { Score } \\
\text { Actual }\end{array}$ & $\begin{array}{c}\text { Score } \\
\text { Max }\end{array}$ & $(\%)$ & Information \\
\hline \multirow{13}{*}{$\begin{array}{l}\text { Employee } \\
\text { Commitments } \\
\text { (EC) }\end{array}$} & \multirow{3}{*}{ 1. Normative } & KK1.1 & 601 & 820 & 73.29 & high \\
\hline & & KK1.2 & 668 & 820 & 81.46 & high \\
\hline & & KK1.3 & 717 & 820 & 87.44 & the highest \\
\hline & \multicolumn{2}{|c|}{ Normative average value } & 1986 & 2460 & 84,17 & the highest \\
\hline & \multirow{3}{*}{ 2. Sustainable } & KK2.1 & 674 & 820 & 82.19 & high \\
\hline & & KK2.2 & 638 & 820 & 77.80 & high \\
\hline & & KK2.3 & 664 & 820 & 80.98 & high \\
\hline & \multicolumn{2}{|c|}{ Sustainability average value } & 1976 & 2460 & 80.32 & high \\
\hline & \multirow{3}{*}{ 3. Affective } & KK3.1 & 689 & 820 & 84.02 & the highest \\
\hline & & KK3.2 & 705 & 820 & 85.97 & the highest \\
\hline & & KK3.3 & 715 & 820 & 87,19 & the highest \\
\hline & \multicolumn{2}{|c|}{ Affective average value } & 2109 & 2460 & 85.73 & the highest \\
\hline & \multicolumn{2}{|c|}{$\begin{array}{l}\text { The average value of employee } \\
\text { commitment }\end{array}$} & 6071 & 7380 & 82.26 & high \\
\hline
\end{tabular}

Source: (processed for research, 2018)

Comprehensively employee commitment at the University of Jambi consisting of: (1) Normative commitment with an average score of 1986 and a maximum score of 2460 with a percentage level of $84.17 \%$ is a score of 5 means that employee commitment is shown from the necessity to be in the organization due to ethical factors and etiquette due to ethical and moral reasons implemented at the highest level. (2) Continuous commitment with an average score of 1976 and a maximum score of 2460 with a percentage level of $80.32 \%$, then a score of 4 means that sustainable commitment is shown from the economic scale that can be enjoyed by employees if they remain in the organization compared to when resigning from the organization is implemented high. (3) Affective commitment with an average score of 2109 and a maximum score of 2460 with a percentage level of $85.73 \%$, then a score of 5 means that affective commitment is an emotional bond, identification, and involvement of employees is implemented the highest. 
Job Performance Description. As the whole work performance at the University of Jambi consisting of: (1) Quality of work with an average score of 2026 and a maximum score of 2460 with a percentage level of $82.36 \%$ thus, the score is 4 means that the quality of work is shown in terms of accuracy concerning time, skill and personality in carrying out these tasks implemented high. (2) Work quantity with an average score of 2038 and a maximum score of 2460 with a percentage level of $82.84 \%$, it is a score of 4 meaning that the quantity of work shown from the provision of additional tasks given is high implemented. (3) Responsibilities with an average score of 2054 and a maximum score of 2460 with a percentage level of $83.49 \%$, a score of 4 means that the responsibilities relating to the result of work completed and the use of work facilities are highly implemented. (4) Cooperation with an average score of 2104 and a maximum score of 2460 with a percentage level of $85.53 \%$, a score of 5 means that the behavior or actions shown by each employee by conducting cooperation so that the work can be completed are better implemented at the highest level. (5) Initiatives with an average score of 2018 and a maximum score of 2460 with a percentage level of $82.03 \%$, then a score of 4 means that initiatives related to the extent to which employees think originally and based on their initiative to solve the problems they face are implemented high.

Descriptions of work performance are implemented as shown in Table 4 below:

Table 4. Description of work performance

\begin{tabular}{|c|c|c|c|c|c|c|}
\hline Variable & Sub-variable & $\begin{array}{c}\text { No } \\
\text { Item } \\
\end{array}$ & $\begin{array}{c}\text { Score } \\
\text { Actual } \\
\end{array}$ & $\begin{array}{c}\text { Score } \\
\text { Max }\end{array}$ & $(\%)$ & Information \\
\hline \multirow{21}{*}{$\begin{array}{l}\text { Work } \\
\text { Performance } \\
\text { (WP) }\end{array}$} & \multirow[t]{2}{*}{ Work Quality } & PK1.1 & 675 & 820 & 82.32 & high \\
\hline & & PK1.2 & 671 & 820 & 81.83 & high \\
\hline & & PK1.3 & 680 & 820 & 82.93 & high \\
\hline & \multicolumn{2}{|c|}{ The average score of quality work } & 2026 & 2460 & 82.36 & high \\
\hline & \multirow[t]{3}{*}{ Work Quantity } & PK2.1 & 688 & 820 & 83.90 & high \\
\hline & & PK2.2 & 680 & 820 & 82.93 & high \\
\hline & & PK2.3 & 670 & 820 & 81.71 & high \\
\hline & \multicolumn{2}{|c|}{ The average score of work quantity } & 2038 & 2460 & 82.84 & high \\
\hline & \multirow[t]{3}{*}{ Responsibility } & PK3.1 & 682 & 820 & 83.17 & high \\
\hline & & PK3.2 & 679 & 820 & 82.80 & high \\
\hline & & PK3.3 & 693 & 820 & 84.51 & the highest \\
\hline & \multicolumn{2}{|c|}{ The average score of responsibility } & 2054 & 2460 & 83.49 & high \\
\hline & \multirow[t]{3}{*}{ Cooperation } & PK4.1 & 721 & 820 & 87.93 & the highest \\
\hline & & PK4.2 & 715 & 820 & 87.19 & the highest \\
\hline & & PK4.3 & 668 & 820 & 81.46 & tinggi \\
\hline & \multicolumn{2}{|c|}{ The average score of cooperation } & 2104 & 2460 & 85.53 & the highest \\
\hline & Initiative & PK5.1 & 694 & 820 & 84.63 & the highest \\
\hline & & PK5.2 & 689 & 820 & 84.02 & the highest \\
\hline & & PK5.3 & 635 & 820 & 77.44 & high \\
\hline & \multicolumn{2}{|c|}{ The average score of Initiative } & 2018 & 2460 & 82.03 & high \\
\hline & \multicolumn{2}{|c|}{$\begin{array}{l}\text { The average score of work } \\
\text { performance }\end{array}$} & 10240 & 12300 & 83.25 & high \\
\hline
\end{tabular}

Source: (processed for research, 2018) 
Description of Remuneration. Overall work performance at Jambi University consisting of: (1) A merit system with an average score of 2046 and a maximum score of 2460 with a percentage level of $83.17 \%$, then a score of 4 means that a merit system which is a performance-based determination of employee income is considered and calculated by referring to the performance appraisal benchmarks highly implemented. (2) Fair with an average score of 2060 and a maximum score of 2460 with a percentage level of $83.74 \%$, then a score of 4 means that it is balanced in the position and workload and the obligations have the same value then it will be paid the same. For tasks that require employees to have specific knowledge in the field, and to have higher skills and power, they will be paid more. Fair is not interpreted in the context that each employee receives benefits that must be the same, but in considering the duties and responsibilities are implemented high. (3) Eligible with an average score of 2005 and a maximum score of 2460 with a percentage level of $81.50 \%$ it is a score of 4 meaning that it can meet the needs of decent living. The benchmarks used to determine employee remuneration are normative rules determined based on applicable regulations. Normative rules are the lowest limits which are prohibited from being highly implemented. (4) Competitive with an average score of 1977 and a maximum score of 2460 with a percentage level of $80.37 \%$, then a score of 4 means competitive, that is, the remuneration of civil servants is equivalent to that in the private sector and the expertise possessed by employees to carry out their duties in accordance with the requirements. This aspect is calculated in the form of rewards that serves to add to the income element obtained in the form of tunjungan and incentives that have been highly implemented. (5) Transparent with an average score of 1981 and a maximum score of 2460 with a percentage level of $80.53 \%$, then a score of 4 means that transparency is openness in determining remuneration by setting conditions for the increase, each of which must be known and easily understood by employees highly implemented.

A description of the remuneration implemented is shown in Table 5 below.

Table 5. Description of Remuneration

\begin{tabular}{|c|c|c|c|c|c|c|}
\hline Variable & Sub-variable & No Item & $\begin{array}{c}\text { Score } \\
\text { Actual }\end{array}$ & $\begin{array}{c}\text { Score } \\
\text { Max }\end{array}$ & $(\%)$ & Information \\
\hline \multirow[t]{16}{*}{ Remunerasi } & \multirow[t]{3}{*}{ Merit Systems } & RM1.1 & 653 & 820 & 79.63 & high \\
\hline & & RM1.2 & 691 & 820 & 84.27 & the highest \\
\hline & & RM1.3 & 702 & 820 & 85.61 & the highest \\
\hline & \multicolumn{2}{|c|}{ Average score of merit systems } & 2046 & 2460 & 83.17 & high \\
\hline & \multirow[t]{3}{*}{ Fair } & RM2.1 & 681 & 820 & 83.05 & high \\
\hline & & RM2.2 & 676 & 820 & 82.44 & high \\
\hline & & RM2.3 & 703 & 820 & 85.73 & the highest \\
\hline & \multicolumn{2}{|c|}{ The average score of fair } & 2060 & 2460 & 83.74 & high \\
\hline & \multirow{3}{*}{ Feasible } & RM3.1 & 680 & 820 & 82.93 & high \\
\hline & & RM3.2 & 679 & 820 & 82.80 & high \\
\hline & & RM3.3 & 646 & 820 & 78.78 & high \\
\hline & \multicolumn{2}{|c|}{ The average score of feasible } & 2005 & 2460 & 81.50 & high \\
\hline & \multirow[t]{3}{*}{ Competitive } & RM4.1 & 659 & 820 & 80.37 & high \\
\hline & & RM4.2 & 634 & 820 & 77.32 & high \\
\hline & & RM4.3 & 683 & 820 & 83.29 & high \\
\hline & \multicolumn{2}{|c|}{ The average score of competitive } & 1977 & 2460 & 80.37 & high \\
\hline
\end{tabular}


Rosita, Fithriani and Widiasuti: Employee Commitment to Improving...

\begin{tabular}{l|l|l|l|l|l|l}
\hline & Transparent & RM5.1 & 652 & 820 & 79.51 & high \\
\cline { 2 - 6 } & & RM5.2 & 648 & 820 & 79.02 & high \\
\cline { 2 - 6 } & \multicolumn{2}{|l}{ RM5.3 } & 681 & 820 & 83.05 & high \\
\cline { 2 - 6 } & \multicolumn{2}{l}{ The average score of transparent } & 1981 & 2460 & 80.53 & high \\
\cline { 2 - 6 } & Score average & 10073 & 12300 & 81.89 & high \\
\hline
\end{tabular}

Source: (processed for research, 2018)

Test the validity and reliability. The result of questionnaires data processing from 164 civil servants indicates that the value of loading for each item of a statement with the construct of employee commitment, work performance, and remuneration can be seen in Figure 2 below:

Figure 2. Value of loading statement items with constructs of employee commitment, work performance, and remuneration

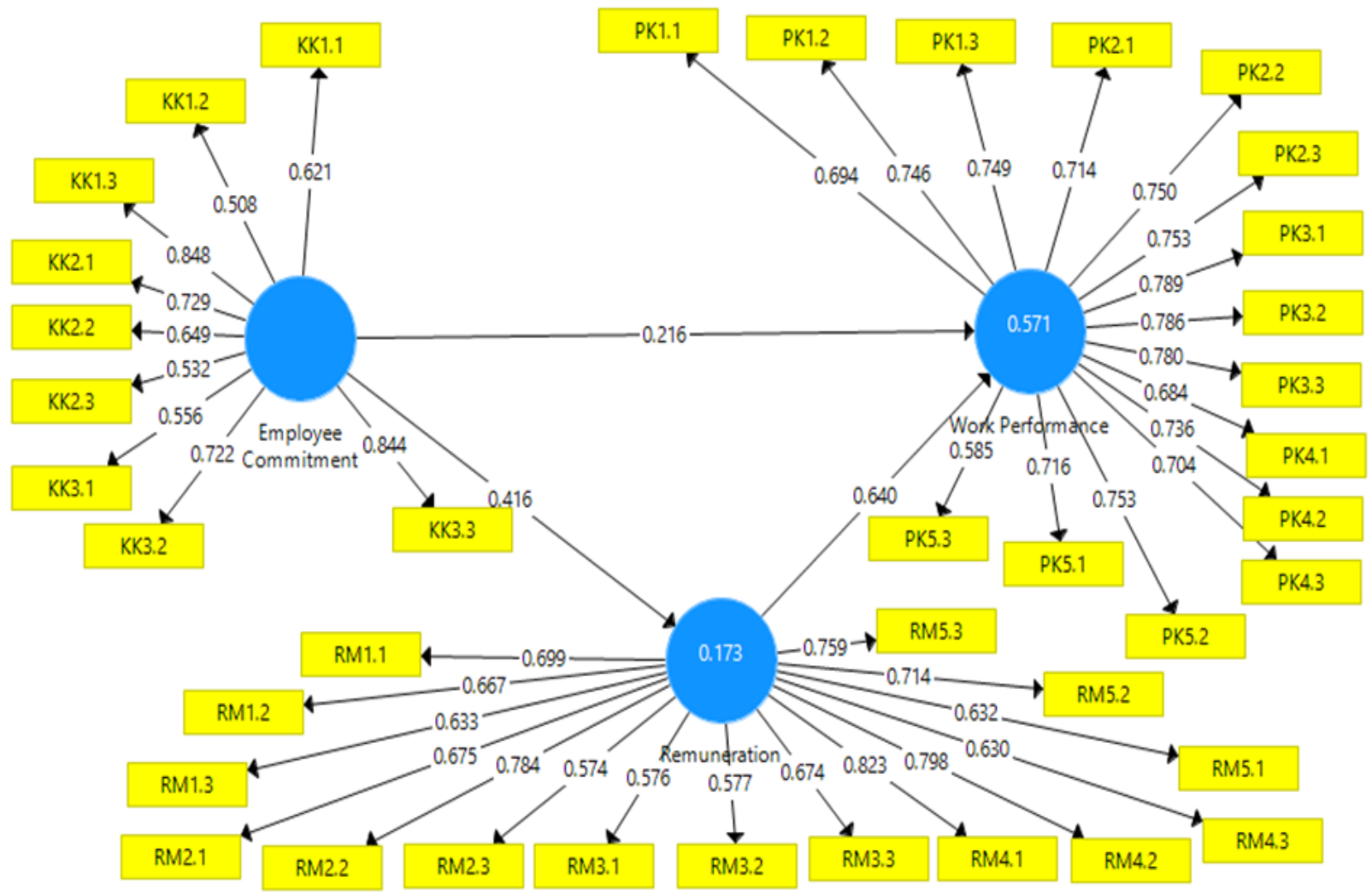

Source: (Processed for research, 2018)

According to (Ghozali, 2015) item statement above 0.50 means that the item is entirely valid, to ensure that there are no problems with measurement then the next step is to test the uni-dimensionality of the model. The uni-dimensionality test is carried out using composite reliability and Cronbach's alpha indicators. Composite reliability measures the results of the reliability of the indicators contained in a construct. A construct can fulfill composite reliability if it has a reliability result $>0.7$. The composite reliability results in the construct can be seen in Table 6 below: 
Table 6. Composite Reliability and Alpha Cronbach

\begin{tabular}{l|c|c}
\hline & Composite Reliability & Alpha Cronbach's \\
\hline $\begin{array}{l}\text { Employee } \\
\text { Commitment }\end{array}$ & 0.881 & 0.862 \\
\hline Work Performance & 0.945 & 0.937 \\
\hline Remuneration & 0.929 & 0.918 \\
\hline
\end{tabular}

Source: (Results of research data processing, 2018)

The composite reliability value for all constructs of employee commitment, work performance and remuneration is greater than 0.7 so that it can be stated to be by the requirements. Also, the reliability value supports alpha Cronbach value which showed that the value of the variable employee commitment, work performance and remuneration above 0.6 which proves that the measurements in this study are reliable.

Path Coefficients. Based on the results of tests on the model performed using a tiered equation model or sequential equation modeling with the SmartPLS 3.0 program, the path coefficients can be obtained as shown in Figure 3 below:

Figure 3. Path coefficients of employee commitment, work performance, and remuneration

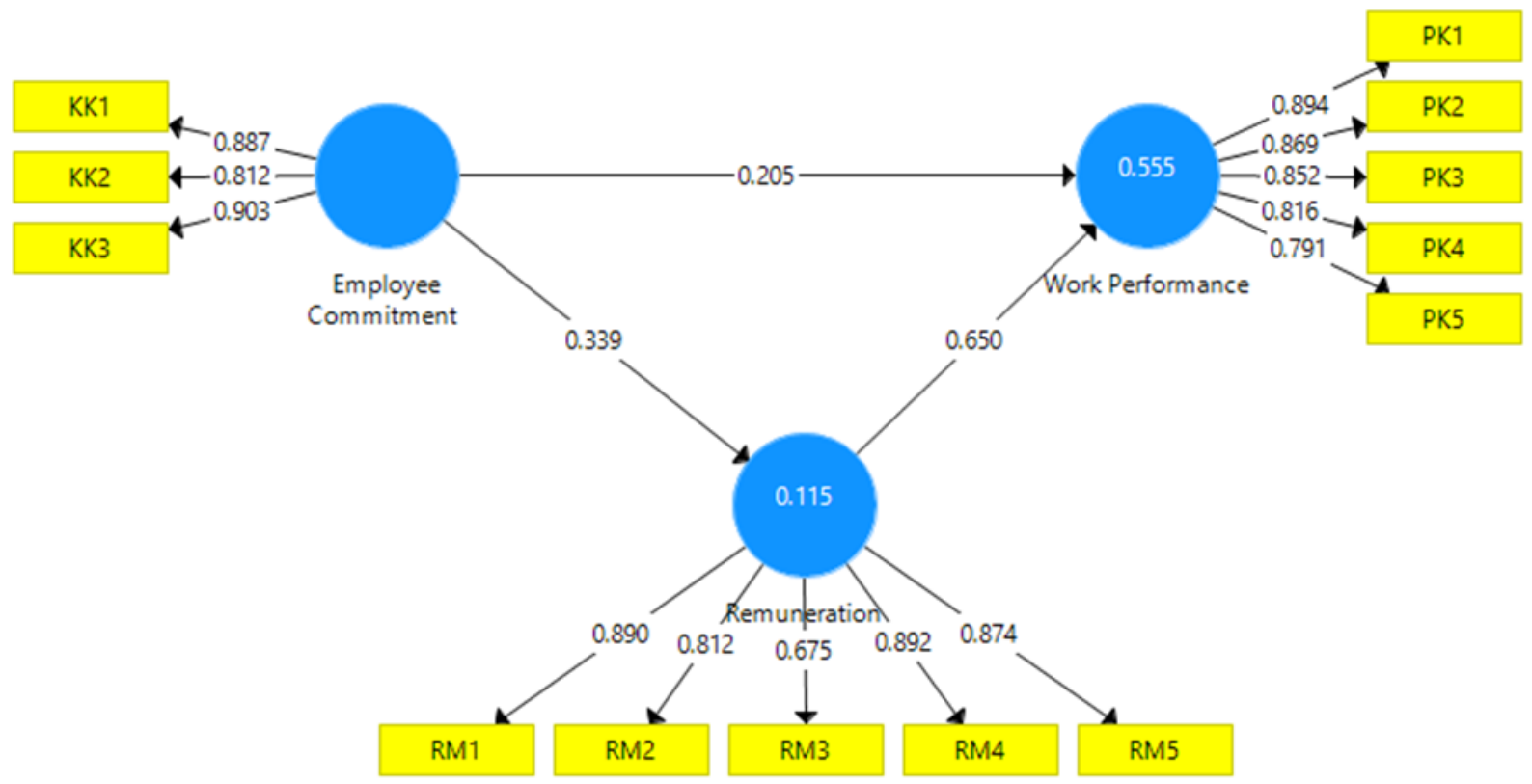

Source: (processed for research, 2018)

The magnitude of the parameter coefficient for employee commitment (EC) to the work performance construct (WP) of 0.205 can be interpreted that employee commitment can make a positive contribution to employee performance as seen from the work results of employees in a certain period by comparing work standards, targets and targets with, In other words, increasing work commitment will increase employee work performance. The 
magnitude of the parameter coefficient for construct employee commitment (EC) on work performance (WP) through remuneration (RM) can be known based on the magnitude of the parameter coefficient for employee commitment construct (EC) to remuneration construct (RM) of 0.339 and the parameter coefficient for construct remuneration construct (RM) to work performance (EC) of 0.650. The results of PLS workout if the employee commitment construct (EC) to the work performance construct (WP) through the remuneration construct (RM) with a specific indirect effect of 0.221 which means the parameter coefficient between employee commitment (EP) to the work performance construct (WP) through remuneration (RM) can be interpreted that employee commitment (EC) possessed by employees has a positive effect on work performance (WP) that can be seen from the results of work through remuneration mediators (RM).

Hypothesis test on statistical calculations can be known through the output parameters as in table 7 below:

Table 7. Total Effects

\begin{tabular}{l|c|c|c|c|c}
\hline & $\begin{array}{l}\text { Original } \\
\text { Sample (O) }\end{array}$ & $\begin{array}{l}\text { Sample } \\
\text { Mean (M) }\end{array}$ & $\begin{array}{l}\text { Standard } \\
\text { Deviation } \\
\text { (STDEV) }\end{array}$ & $\begin{array}{l}\text { T Statistics } \\
(\mid \text { O/STDEV })\end{array}$ & P Values \\
\hline $\begin{array}{l}\text { Employee } \\
\text { Commitment } \rightarrow \\
\text { Work Performance }\end{array}$ & 0.205 & 0.207 & 0.066 & 3.087 & 0.002 \\
\hline $\begin{array}{l}\text { Employee } \\
\text { Commitment } \rightarrow \\
\text { Remuneration }\end{array}$ & 0.339 & 0.348 & 0.084 & 4.054 & 0.000 \\
\hline $\begin{array}{l}\text { Remuneration } \rightarrow \\
\text { Work Performance }\end{array}$ & 0.650 & 0.658 & 0.057 & 11.387 & 0.000 \\
\hline
\end{tabular}

Source: (Data processing result, 2018)

Hypothesis 1: Employee commitment influences improving work performance.

The hypothesis which stated that employee commitment has an influence on work performance has strong support (hypothesis is acceptable). This result is consistent with the initial prediction (hypothesis), that employee commitment influences work performance.

Hypothesis 2: Employee commitment influences improving work performance with remuneration as a mediator variable.

The hypothesis which stated that employee commitment has an influence in improving work performance with remuneration as a mediator variable has strong support (hypothesis can be accepted). This result is by the initial prediction (hypothesis), Remuneration which is an award given to employees in the form of performance benefits can be a mediator between employee commitment to work performance. 


\section{DISCUSSION}

This study showed that employee commitment has an influence on work performance that can be shown from civil servants always carrying out obligations for organizational goals with ethical and moral reasons, employees feel emotional ties and a sense of need for the organization and think that is assuming leaving the organization that it will very detrimental to themselves, the increasing commitment of employees also increases work performance which can be shown from the quality of work, the quantity of work, responsibility, cooperation, and initiative. This study is in line with research conducted by (Meri and Anwar, 2013) which stated that employee commitment has a significant relationship with employee work performance. Employee commitment has a relationship to improving employee performance. The higher the commitment is shown by the employee, the higher the performance shown by the employee.

Employee commitment influences work performance through remuneration as a mediator variable, in other words, remuneration is a mediator between employee commitment to work performance. Remuneration which is defined generally as an award in the form of money refers to a system of merit, fair, decent, competitive, and transparent is a mediator between employee commitments to work performance. The effect of remuneration as an award in the form of money is greater as a mediator than the direct effect of employee commitment on work performance.

This research supported research conducted by Yuliani (2015) remuneration system influences employee performance, remuneration is given by the company is carried out correctly, to improve employee performance.

\section{CONCLUSION}

The commitment of employees in improving work performance. Employee commitment has an influence on work performance or in other words work performance is the effect of employee commitment. The better the commitment of employees, the more quality work results achieved by employees.

Employee commitment has an influence on work performance with remuneration as a mediator variable. The role of remuneration as a mediator variable is greater than the direct relationship of employee commitment to work performance.

Suggestions. Employee commitment influences work performance, but the effect will be greater if remuneration as a mediator, then the role of remuneration which is reciprocated services provided by the organization to employees will have greater influence in improving work performance. Researching employee commitment to work performance through remuneration as a mediator still leaves potential results to be studied, so for future research, it is recommended to be able to focus on remuneration in improving employee performance so that commitment in work will continue to be owned by employees.

\section{REFERENCES}

Afriadi, H,. (2017). Pengaruh Budaya Kerja, Motivasi Kerja Dan Remunerasi Terhadap Kinerja Karyawan Dengan Komitmen Individual Sebagai Variable Mediating Pada 
Kantor Kesyahbandaran Dan Otoritas Pelabuhan Malahayati, Jurnal Perspektif Manajemen dan Perbankan, 8 (3), www.jurnal.unsyiah.ac.id/JPMP/article/view/10193.

Agrimahera, A. (2013). "Evaluasi Sistem Remunerasi Dosen Badan Layanan Umum Perguruan Tinggi (studi kasus universitas "X")". Jurnal Ilmiah Mahasiswa FEB Universitas Brawijaya 2(1). http://jimfeb.ub.ac.id/index.php/jimfeb/article/view/927.

Akintayo, D.I,. (2012). Work-Family Role Conflict and Organizational Commitment Among Industrial Workers in Nigeria. Journal of Psychology and Counselling, 2(1).

Bol, J. C., Hecht, G. and Smith, S. D. (2015). Managers Discretionary Adjustments: The Influence of Uncontrollable Events and Compensation Interdependence. Contemporary Accounting Research.

Colquitt, J, A., LePine, J, A, and Wesson, M, J, (2015). Organizational behavior: improving performance and commitment in the workplace. Fourth edition. New York: McGraw-Hill Education, 2 Penn Plaza.

Flippo, E,B,. (2012). Personel Management (Manajemen Personalia). Edisi VII Jilid II. Terjemahan Alponso S, Erlangga, Jakarta.

Ghozali, Imam., Latan, Hengky. (2015) Partial Least Squares: Konsep, Teknik dan Aplikasi Menggunakan SmartPLS 3.0, Edisi 2. Universitas Diponegoro.

Handoko. (2012). Manajemen Personalia dan Sumber Daya Manusia. Yogyakarta: BPFE.

Irefin and Mechanic. (2014). Effect of Employee Commitment on Organizational Performance in Coca Cola Nigeria Limited Maiduguri, Borno State. Journal of Humanities And Social Science (IOSR-JHSS), 19 (3). www.iosrjournals.org.

Khan M.R., Ziauddin, Jam F.A. and Ramay M.I. (2012) "The Impacts of Organizational Commitment on Employee Job Performance”. European Journal of Social Sciences 15(3): 292-298.

Lee and Chen. (2013). The Relationship between Employee Commitment and Job Attitude and Its Effect on Service Quality in the Tourism Industry, American Journal of Industrial and Business Management, 3, 196-208. http://www.scirp.org/journal/ajibm.

Mangkunegara, A, P. (2012) Manajemen Sumber Daya Manusia Perusahaan. Bandung: Remaja Rosdakarya.

Meri, S., Anwar, K,. (2013). Perilaku Kepemimpinan, Komitmen Pegawai, dan Prestasi Kerja, Jurnal Administrasi Pembangunan, 1(3), 219-323.

Peraturan Pemerintah Nomor 46 Tahun (2011). Penilaian Prestasi Kerja Pegawai Negeri Sipil.

Peraturan Presiden Republik Indonesia Nomor 32 Tahun (2016). Tunjangan Kinerja Pegawai di Lingkungan Kementerian Riset, Teknologi dan Kependidikan Tinggi.

Robbins, S.P., Judge, T, A. (2017). Organizational Behavior, Pearson Prentice Hall, United State Of America, New York.

Siagian. (2013). Manajemen Sumber Daya Manusia. Bumi Aksara. Jakarta.

Urbancová1 and Šnýdrová1. (2017). Remuneration and Employee Benefits in Organizations in the Czech Republic. Acta Universitatis Agriculturae et Silviculturae Mendelianae Brunensis, 65 https://doi.org/10.11118/actaun201765010357. 
Wilfred. (2014) "Effect of Remuneration on Employees Performance in the Ministry of Internal Security: A Case of Kisii County". International Journal of Human Resource Studies 4 (1). DOI: http://dx.doi.org/10.5296/ijhrs.v4i1.5478.

Yuliani, E. (2015). Pengaruh Sistem remunerasi terhadap prestasi kerja karyawan pada $\begin{array}{llll}\text { Perusahaan PT Betjik Djojo } & \text { Surabaya. }\end{array}$ https://ejournal.stiesia.ac.id/jirm/article/download/453/435.

Zheng W., Sharan K. and Wei J. (2010). New Development of Organizational Commitment: A Critical Review (1960-2009). African Journal of Business Management, 4(1), Pp. 12-20. 